\title{
Detection of enterotoxigenic Clostridium perfringens with a duplex PCR
}

\author{
E. AUGUSTYNOWICZ, A. GZYL and J. ŚLUSARCZYK
}

Department of Sera and Vaccines Evaluation, National Institute of Hygiene, 24 Chocimska Street, 00-791 Warsaw, Poland

\begin{abstract}
Two sets of primers designed to detect Clostridium perfringens phospholipase C (plc) and enterotoxin (cpe) genes in a single PCR reaction were applied to a collection of 64 predominantly food poisoning-related $C$. perfringens isolates. In-vitro enterotoxin synthesis was tested serologically after inducing sporulation. Of the 64 isolates, 26 were clearly enterotoxigenic; 16 were classified as potentially enterotoxigenic only as serological testing did not confirm enterotoxin production. Duplex PCR for diagnosis of enterotoxigenic $C$. perfringens from vegetative cultures can be a useful tool as fresh isolates often sporulate poorly or not all, giving rise to the possibility of false negative results by serological analysis.
\end{abstract}

\section{Introduction}

Clostridium perfringens type A produces an enterotoxin (CPE) and can cause food poisoning outbreaks with diarrhoea and severe abdominal pain related to the consumption of food $[1,2]$. Several hundred cases of food poisoning associated with $C$. perfringens type A occur in the USA and Europe every year [3]. CPE induces clinical symptoms in vivo within 15-30 min of delivery of purified toxin [4]. In man, symptoms develop when $>5 \times 10^{8}$ viable enterotoxigenic vegetative cells of $C$. perfringens reach the digestive system [1]. Detection of $C$. perfringens in faeces and consumed food, together with the identification of a common serotype, is widely applied for outbreak characterisation. However, this approach is not always sufficient to completely describe an outbreak. The classical approach to $C$. perfringens food poisoning involves the detection of $>10^{6}$ bacterial cells $/ g$ in faecal samples or serological detection of CPE after inducing sporulation of an isolate, or both [5]. Characterisation of enterotoxigenic $C$. perfringens isolates can be difficult as the ability to sporulate in vitro can vary with different media [6]. Moreover, CPE synthesis can occur in nonsporulating cultures of $C$. perfringens [3]. Detection of enterotoxin by immunoenzymic methods, e.g., immunoelectrophoresis, latex agglutination, immunodiffusion, ELISA, Western blot or reverse passive latex agglutination (RPLA) requires relatively large amounts of CPE in a sample and has many interpretation problems [5].

Received 5 Jan. 2000;revised version accepted 27 July 2001. Corresponding author: $\mathrm{Dr}$ E. Augustynowicz (e-mail: eaugustynowicz@pzh.gov.pl).
Therefore, new diagnostic approaches are required for confirmation of food poisoning with $C$. perfringens. One option may be the identification by PCR or hybridisation methods [6-12] of genes encoding information on CPE and other toxins.

This study aimed to identify enterotoxigenic isolates of $C$. perfringens by amplification of fragments of genes encoding phospholipase $\mathrm{C}(p l c)$ and enterotoxin (cpe) in a single PCR and to compare enterotoxin gene detection with CPE protein detection by serological means.

\section{Materials and methods}

\section{Bacterial strains}

A set of lyophilised isolates of $C$. perfringens collected during the period 1954-1999 at the Department of Sera and Vaccines Evaluation, National Institute of Hygiene, Warsaw, Poland, was used for the study. The collection consisted of 64 type A strains associated mainly with food poisoning cases: 30 from stool samples, 10 from gastric lavage, 20 from food samples and 4 from wound biopsies.

Isolates were cultured on Merck $C$. perfringens selective agar plates and SPS agar (Merck) in anaerobic jars containing $\mathrm{H}_{2} 95 \%$ and $\mathrm{CO}_{2} \quad 5 \%$.

Seven toxin-typed reference strains of $C$. perfringens, type A strains CN3352 cpe ${ }^{-}$and $\mathrm{CN} 3418$ cpe $^{+}$, type B strain ATCC 3626, type C strain CN5386, type D strain CN1183 and type E strain NCTC 8084, were used as controls. The specificity of the PCR was tested 
with several isolates belonging to the genus Clostridium C. difficile, C. bifermentans, C. novyi, $C$. histolyticum, C. septicum, C. sordelli, C. fallax, $C$. capitalle, $C$. oedematiens and isolates belonging to other genera (Escherichia coli, Salmonella enteritidis, Staphylococcus aureus, Bacillus cereus). A further 24 isolates of C. perfringens belonging to types $\mathrm{B}, \mathrm{C}, \mathrm{D}$ or $\mathrm{E}$ were analysed.

\section{Identification of $C$. perfringens}

C. perfringens isolates were identified by Gram's stain, urease and lecithinase production, and other biochemical tests as described previously [10]. Toxinotypes of C. perfringens isolates were determined by neutralisation of lethality in mice.

\section{Enterotoxin detection by RPLA}

For testing of enterotoxin production, isolates were grown at $37^{\circ} \mathrm{C}$ for $24 \mathrm{~h}$ in the sporulation medium of Ellner [13], before being heated at $75^{\circ} \mathrm{C}$ for $20 \mathrm{~min}$. Then, $16 \mathrm{ml}$ of fresh Ellner medium were inoculated with $0.8 \mathrm{ml}$ of culture (taken from base of the tube) and incubated at $37^{\circ} \mathrm{C}$ for $24 \mathrm{~h}$. After incubation, samples were centrifuged at $900 \mathrm{~g}$ for $20 \mathrm{~min}$ at $4^{\circ} \mathrm{C}$ and the supernate was used in a PET-RPLA test (Oxoid) according to the manufacturer's instructions.

\section{Isolation of DNA}

Overnight $C$. perfringens cultures on SPS agar were suspended in TE buffer $10 \mathrm{mM}$ Tris; $1 \mathrm{mM}$ EDTA then centrifuged at $6000 \mathrm{~g}$ for $10 \mathrm{~min}$, the pellet was resuspended in $567 \mu \mathrm{l}$ of TE buffer and incubated for $1 \mathrm{~h}$ at $37^{\circ} \mathrm{C}$. After adding $30 \mu \mathrm{l}$ of SDS $10 \%$ and $3 \mu \mathrm{l}$ of proteinase $\mathrm{K}(20 \mathrm{mg} / \mathrm{ml})$, samples were incubated at $37^{\circ} \mathrm{C}$ for $1 \mathrm{~h}$ and then $100 \mu \mathrm{l}$ of $5 \mathrm{M} \mathrm{NaCl}$ and $80 \mu \mathrm{l}$ of CTAB-NaCl solution (cetyl trimethyl ammonium bromide $10 \%$ in $0.7 \mathrm{M} \mathrm{NaCl}$ ) were added before incubation for $10 \mathrm{~min}$ at $65^{\circ} \mathrm{C}$. DNA was extracted with phenol:chloroform:isoamyl alcohol (25:24:1) solution and precipitated with absolute ethanol overnight at $-20^{\circ} \mathrm{C}$. The DNA was harvested by centrifugation at $12000 \mathrm{~g}$ for $20 \mathrm{~min}$, washed with ethanol $70 \%$ and dissolved in $100 \mu \mathrm{l}$ of TE buffer. The concentration and the quality of the DNA were measured spectrophotometrically at 260 and $280 \mathrm{~nm}$. DNA from species other than $C$. perfringens was extracted with the QIAamp Mini Kit (Qiagen).

\section{Amplification}

PCR to detect plc and cpe genes was performed with primers that had been developed and validated by Fach and Popoff [9]. PL3-5' AAGTTACCTTTGCTGCAT AATCCC 3' PL7-5' ATAGATACTCCATATCATCC TGCT $3^{\prime}$ and PL145-5' GAAAGATCTGTATCTACA ACTGCTGGTCC 3', PL146-5' GCTGGCTAAGAT TCTATATTTTTGTC CAGT 3' yield a 283-bp frag- ment for the plc gene and a 426-bp fragment for the cpe gene in enterotoxigenic $C$. perfringens isolates. PCR was performed in a $50-\mu 1$ reaction volume. The mixture contained $1 \times$ buffer $(10 \mathrm{mM}$ Tris $\mathrm{HCl}, \mathrm{pH} 8.3$; $50 \mathrm{mM} \mathrm{KCl}$; gelatin $0.001 \% 2.5 \mathrm{mM} \mathrm{MgCl}_{2} ; 100 \mu \mathrm{M}$ each dNTP (Gibco); 20 pmol of primers (synthesised by Universal DNA., USA); Taq polymerase (Biometra) $1.25 \mathrm{U}$ and template DNA $100 \mathrm{ng}$. PCR was performed with the following conditions: $30 \mathrm{~s}$ at $94^{\circ} \mathrm{C}$, followed by 30 cycles consisting of $30 \mathrm{~s}$ at $94^{\circ} \mathrm{C}, 30 \mathrm{~s}$ at $55^{\circ} \mathrm{C}$ and $30 \mathrm{~s}$ at $72^{\circ} \mathrm{C}$.

\section{PCR sensitivity}

Sensitivity of the PCR reaction was confirmed with a reference strain $(C$. perfringens $\mathrm{CN} 3352)$ cultured in Reinforced Clostridial Broth (RCM, Merck). Ten-fold dilutions of culture were subjected to DNA extraction by the phenol method. Viable counts were done at the same time, and the lowest number of bacterial cells that could be detected by PCR was determined.

\section{Detection of PCR products}

Amplified PCR products were electrophoresed in agarose gel containing ethidium bromide $0.5 \mu \mathrm{g} / \mathrm{ml}$, observed under UV illumination and photographed with a Polaroid camera. Precise band size was determined densitometrically (Gel Doc 1000 Gel Documentation System, BioRad).

\section{Results}

Initially, the specificity of primers designed to amplify the plc and cpe genes was investigated with several clostridial and non-clostridial species previously associated with food poisoning. Both the plc and cpe gene fragments were amplified in the duplex PCR with DNA extracted from control cpe ${ }^{+}$C. perfringens type A CN3418, a known enterotoxin producer. For CN3352, a cpe ${ }^{-}$known non-CPE producer, the 283-bp fragment of $p l c$ gene was present; however, the 426-bp fragment of the cpe gene was not. Similarly, in $24 C$. perfringens isolates of $\mathrm{B}, \mathrm{C}, \mathrm{D}$ or $\mathrm{E}$ types, cpe gene fragments were not observed, while in every case the $p l c$ amplicon was seen. No cross-reaction with other Clostridium species or with other bacteria was observed. The sensitivity of PCR with both sets of primers, PL3/PL7 ( $p l c$ gene) and PL145/PL146 (cpe gene), used in combination, was $10-20$ bacterial cells from RCM.

Sporulation was seen in 63 of the 64 strains tested. All strains that sporulated successfully were subsequently tested for in-vitro CPE production by RPLA. A comparison of duplex PCR and RPLA results is presented in Table 1. Amplification of the plc gene encoding phospholipase $\mathrm{C}$ was successful for all $64 \mathrm{C}$. perfringens strains tested. In $42(66 \%)$ of the 64 strains the 426-bp fragment of the cpe gene encoding 
Table 1. A comparison of detection of plc and cpe genes by PCR and detection of enterotoxin by RPLA in C. perfringens strains*

\begin{tabular}{lcccc}
\hline & & \multicolumn{2}{c}{ Number $(\%)$ of strains that were } \\
\cline { 3 - 5 } Strain source & $\begin{array}{c}\text { Number of } \\
\text { strains tested }\end{array}$ & $\begin{array}{c}\text { plct cpe } \\
\text { CPE- }\end{array}$ & $\begin{array}{c}\text { plc }+ \text { cpe }+ \\
\text { CPE }+\end{array}$ & $\begin{array}{c}\text { plc }+ \text { cpe }+ \\
\text { CPE- }\end{array}$ \\
\hline Stool samples & 30 & 7 & 16 & 7 \\
Gastric lavage & 10 & 5 & 3 & 2 \\
Food samples & 20 & 8 & 6 & 6 \\
Wounds & 3 & 1 & 1 & 1 \\
Total & 63 & $21(33 \%)$ & $26(41 \%)$ & $16(25 \%)$ \\
\hline
\end{tabular}

*For a single non-sporulating strain isolated from a wound, a profile of plc(+)cpe (-) was obtained.

enterotoxin was amplified. Representative results for plc and cpe gene identification by duplex PCR are presented in Fig. 1.

\section{Discussion}

C. perfringens type A strains are frequently isolated from the environment and from the digestive tract of man and animals. They can be a cause of food poisoning outbreaks when they are enterotoxin producers $[1,3]$. There is a correlation between CPE synthesis and spore formation, and this is the basis for enterotoxigenic and non-enterotoxigenic strain differentiation [1]. However, there are some limitations to inducing sporulation of $C$. perfringens isolates in vitro on different media $[3,6,10]$. Sequencing of the genes encoding synthesis of phospholipase $\mathrm{C}$ and enterotoxin has enabled the introduction of a PCR for the identification and typing of $C$. perfringens strains $[8-10,14,15]$. Direct isolation of DNA from vegetative $C$. perfringens cells eliminates the need for $C$. perfringens isolates to sporulate in order to obtain toxin in quantities needed for serological tests [16].
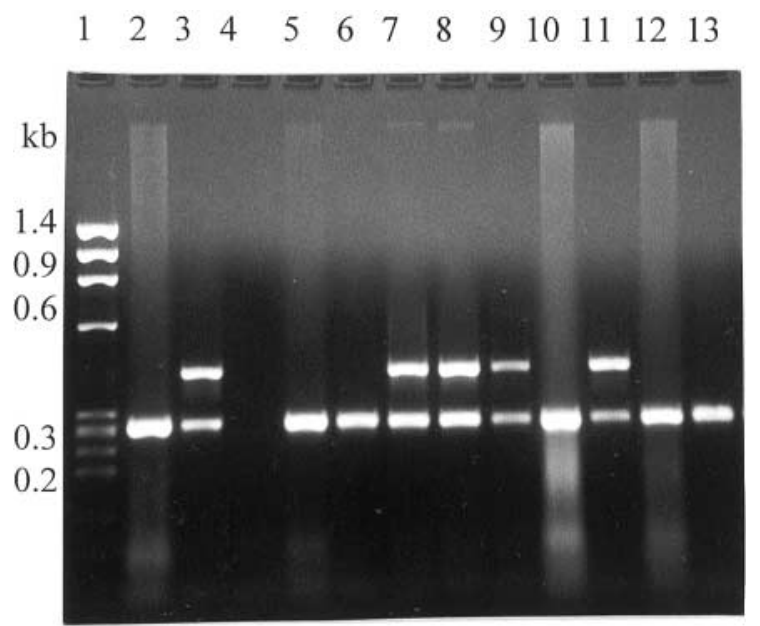

Fig. 1. Results of $p l c$ and cpe gene amplification (duplex PCR) in DNA extracted from C. perfringens strains isolated from stool samples of patients with food poisoning. 1, $\varphi$ X174 RFI DNA/HaeIII marker; 2, C. perfringens CN3352 cpe control strain; 3, C. perfringens $\mathrm{CN} 3418$ cpe $^{+}$control strain; 4, negative PCR control; 5, 6, 10, 12, 13, C. perfringens plc ${ }^{+}$, cpe ${ }^{-}$strains; $\mathbf{7}, \mathbf{8}, \mathbf{9}, \mathbf{1 1}$, C. perfringens plc ${ }^{+}$, cpe ${ }^{+}$strains.
Toxin detection and typing of $C$. perfringens by multiplex PCR in stool or food samples or culture supernates was first described by Miwa et al. [7] and Meer and Songer [17]. In the present study, two sets of primers applied in a duplex PCR enabled the identification of enterotoxigenic $C$. perfringens. One pair of primers designed for the phospholipase $\mathrm{C}$ gene ( $p l c$ ) provided specific identification of $C$. perfringens as the plc gene is located on the chromosome of all $C$. perfringens types [18]. A second pair of primers was derived from the cpe gene, which is also chromosomally located in $C$. perfringens $c p e^{+}$isolates from human clinical material [19]. For DNA extracted from C. perfringens RCM cultures, the sensitivity was 1020 bacterial cells. Yoo et al. [19] were able to detect toxin genes with a sensitivity of $10 \mathrm{pg}$ of DNA. Fach and Popoff [9] showed that PCR could detect the enterotoxin gene in clinical material, food and samples from the environment with a sensitivity of 10 bacterial cells, sufficient for routine food testing.

van Damme-Jongsten et al. [11] reported that only 6\% of $C$. perfringens isolates from a wide variety of sources contained the cpe gene. However, the cpe gene was found in $59 \%$ of isolates from food samples or stools from patients with food poisoning (66\% in food samples and $57 \%$ in stool samples) [6]. The present study detected the cpe gene by PCR in $70 \%$ of $C$. perfringens isolates from food poisoning cases. Previous serological studies have shown that only sporulating $C$. perfringens type $\mathrm{A}$ are capable of producing CPE $[6,20,21]$. The expression of cpe mRNA and CPE protein synthesis was strongly blocked in cells in the vegetative stage of growth, increasing up to 1500 times after starting the sporulation process $[20,22]$. The present study could not confirm the recently published evidence of enterotoxin synthesis by C. perfringens types C and D $[9,19]$, and the cpe gene was seen only with $C$. perfringens type A [23].

van Damme-Jongsten et al. [6] showed that 19 of $20 C$. perfringens isolates with the cpe gene produced $\mathrm{CPE}$ protein in vitro. In the present study, only 26 of 42 isolates containing the cpe gene produced CPE detectable by RPLA. These differences may reflect low levels of toxin produced or low RPLA sensitivity. However, in-vitro sporulation for CPE for identification 
of enterotoxigenic $C$. perfringens isolates may not be reliable. Although there is evidence that $40 \%$ of even fresh $c p e^{+} C$. perfringens isolates fail to sporulate in different growth conditions, only one strain of the 64 isolates in the present study did not sporulate in vitro in Ellner's medium. However, serological examination showed that only $35 \%$ of isolates analysed were able to synthesise CPE toxin [5]. Thus, the $26 \mathrm{cpe}^{+} \mathrm{CPE}^{+}$ $C$. perfringens isolates were clearly causes of enterotoxic infection.

The 16 cpe $^{+} \mathrm{CPE}^{-}$sporulating isolates are likely to be enterotoxigenic because they were isolated from patients with food poisoning and diarrhoea, or implicated food, or both. Negative results by RPLA could be false negatives as a result of too low a level of CPE synthesis. Furthermore, not all $C$. perfringens type A isolates induce a lethal effect in mice, suggesting different enterotoxin production levels, or a lack of enterotoxin in some strains [23]. The differences in clinical presentation seen in cases of $C$. perfringens type A infection may be related to different levels of enterotoxin production [24].

It is possible that $c p e^{+} \mathrm{CPE}^{-}$isolates may represent 'false positives'. The isolates may not be producing the regulatory factors required for CPE expression. Therefore, such strains should rather be referred to only as potentially enterotoxigenic, unless $\mathrm{CPE}$ production can be confirmed. It is also possible that $c p e^{+} \mathrm{CPE}^{-}$ sporulating or non-sporulating isolates are normal flora of the gut. The detection of $c p e^{+} \mathrm{CPE}^{-}$isolates, especially those that are non-sporulating, should be interpreted with caution [19].

Nineteen $\mathrm{plc}^{+}$cpe $e^{-} \mathrm{CPE}^{-}$isolates were classified as a 'not enterotoxigenic' cause of food poisoning. Because $C$. perfringens is frequently distributed in the environment and present in the intestinal tract of man, food and faeces may be easily contaminated with different enterotoxin-producing strains.

In summary, compared to RPLA, PCR is a useful technique for analysis of strains suspected of being the cause of food poisoning. However, enterotoxigenicity should still be confirmed by in-vitro CPE detection, if possible, after gene identification. Duplex PCR is highly specific for $C$. perfringens and is able to discriminate potentially enterotoxigenic strains. Its sensitivity allows for direct application to clinical material and food samples and it can easily be applied to screen strains/ clinical material before serological examinations to exclude isolates lacking the cpe gene which are not potentially enterotoxigenic.

\section{References}

1. Hatheway CL. Toxigenic Clostridia. Clin Microbiol Rev 1990; 3: $66-98$.

2. Stevens DL, Bryant AE. Pathogenesis of Clostridium perfringens infection: mechanisms and mediators of shock. Clin Infect
Dis 1997; 25 Suppl 2: S160-S164.

3. Petit L, Gibert M, Popoff MR. Clostridium perfringens: toxinotype and genotype. Trends Microbiol 1999; 7: 104-110.

4. Smith LDS. Virulence factors of Clostridium perfringens. Rev Infect Dis 1979; 1: 254-262.

5. Berry PR, Rodhouse JC, Hughes S, Bartholomew BA, Gilbert RJ. Evaluation of ELISA, RPLA, and Vero cell assays for detecting Clostridium perfringens enterotoxin in faecal specimens. J Clin Pathol 1988; 41: 458-411.

6. van Damme-Jongsten M, Rodhouse J, Gilbert RJ, Notermans S. Synthetic DNA probes for detection of enterotoxigenic Clostridium perfringens strains isolated from outbreaks of food poisoning. J Clin Microbiol 1990; 28: 131-133.

7. Miwa N, Nishina T, Kubo S, Fujikura K. Nested polymerase chain reaction for detection of low levels of enterotoxigenic Clostridium perfringens in animal feces and meat. $J$ Vet Med Sci 1996; 58: 197-203.

8. Baez LA, Juneja VK, Sackitey SK. Chemiluminescent enzyme immunoassay for detection of PCR-amplified enterotoxin A from Clostridium perfringens. Int J Food Microbiol 1996; 32: 145-158.

9. Fach P, Popoff MR. Detection of enterotoxigenic Clostridium perfringens in food and fecal samples with a duplex PCR and the slide latex agglutination test. Appl Environ Microbiol 1997; 63: $4232-4236$.

10. Kokai-Kun JF, Songer JG, Czeczulin JR, Chen F, McClane BA. Comparison of Western immunoblots and gene detection assays for identification of potentially enterotoxigenic isolates of Clostridium perfringens. $J$ Clin Microbiol 1994; 32: 2533-2539.

11. van Damme-Jongsten M, Wernars K, Notermans, S. Cloning and sequencing of the Clostridium perfringens enterotoxin gene. Antonie van Leeuwenhoek 1989; 56: 181-190.

12. Daube G, Simon P, Limbourg B, Manteca C, Mainil J, Kaeckenbeeck A. Hybridization of 2659 Clostridium perfringens isolates with gene probes for seven toxins (alpha, beta, epsilon, iota, theta, mu, and enterotoxin) and for sialidase. $\mathrm{Am}$ $J$ Vet Res 1996; 57: 496-501.

13. Duncan CL, Strong DH, Sebald M. Sporulation and enterotoxin production by mutants of Clostridium perfringens. J Bacteriol 1972; 110: 378-391.

14. Canard B, Cole ST. Genome organization of the anaerobic pathogen Clostridium perfringens. Proc Natl Acad Sci USA 1989; 86: 6676-6680.

15. Canard B, Saint-Joanis B, Cole ST. Genomic diversity and organization of virulence genes in the pathogenic anaerobe Clostridium perfringens. Mol Microbiol 1992; 6: 1421-1429.

16. Nagahama M, Kobayashi K, Ochi S, Sakurai J. Enzyme-linked immunosorbent assay for rapid detection of toxins from Clostridium perfringens. FEMS Microbiol Lett 1991; 84: 41-44.

17. Meer RR, Songer JG. Multiplex polymerase chain reaction assay for genotyping Clostridium perfringens. Am J Vet Res 1997; 58: 702-705.

18. Tso JY, Siebel CH. Cloning and expression of the phospholipase $\mathrm{C}$ gene from Clostridium perfringens and Clostridium bifermentans. Infect Immun 1989; 57: 468-476.

19. Yoo HS, Lee SU, Park KY, Park YH. Molecular typing and epidemiological survey of prevalence of Clostridium perfringens types by multiplex PCR. J Clin Microbiol 1997; 35: 228-232.

20. Melville SB, Labbe R, Sonenshein AL. Expression from the Clostridium perfringens cpe promoter in Clostridium perfringens and Bacillus subtilis. Infect Immun 1994; 62: 5550-5558.

21. Ninomiya M, Matsushita O, Minami J, Sakamoto H, Nakano M, Okabe A. Role of alpha- toxin in Clostridium perfringens infection determined by using recombinants of $C$. perfringens and Bacillus subtilis. Infect Immun 1994; 62: 5032-5039.

22. Czeczulin JR, Hanna PC, McClane BA. Cloning, nucleotide sequencing, and expression of the Clostridium perfringens enterotoxin gene in Escherichia coli. Infect Immun 1993; 61: 3429-3439.

23. Mietzner TA, Kokai-Kun JF, Hanna PC, McClane BA. A conjugated synthetic peptide corresponding to the C-terminal region of Clostridium perfringens type A enterotoxin elicits an enterotoxin-neutralizing antibody response in mice. Infect Immun 1992; 60: 3947-3951.

24. Czeczulin JR, Collie RE, McClane BA. Regulated expression of Clostridium perfringens enterotoxin in naturally cpe-negative type $\mathrm{A}, \mathrm{B}$, and $\mathrm{C}$ isolates of $C$. perfringens. Infect Immun 1996; 64: 3301-3309. 